\title{
CEREBROSPINAL FLUID CYTOLOGICAL AND BIOCHEMICAL CHARACTERISTICS IN THE PRESENCE OF CNS NEOPLASIA
}

\author{
Sérgio M. de Almeida, Edna Nanakanishi, Arnaldo J. de Conto, \\ Luciana P. Souza, Dario Antonelli Filho, Carlos D. Roda
}

\begin{abstract}
Central nervous system (CNS) infiltration must be ruled out in patients with known neoplastic diseases and neurological symptoms. It was done a retrospective analysis of 1,948 CSF samples from patients with suspected malignant infiltration in the CNS, in order to evaluate the positivity rate of malignant cells in cerebrospinal fluid (CSF) samples and correlate with cytochemical characteristics. Sixty-two percent of subjects had acute lymphocytic leukemia. Malignant cells were found in $24 \%$ of all CSF samples. Subjects with positive malignant cells had predominance of increased levels of CSF total protein (TP), glucose and total cytology $(p<0.05)$. Mean total cell count in this group was 232 (SD 933) cells $/ \mathrm{mm}^{3}$, compared to 9 (SD 93) cells $/ \mathrm{mm}^{3}$ in the group without neoplasic cells $(\mathrm{p}=0.029)$. CSF TP specificity was $87 \%$ and negative predictive value (NPV) $96 \%$. CSF total cell count specificity $86 \%$ and NPV $97 \%$. Although sensitivity and positive predictive value were low. The presence of inflammatory cells and elevated TP found in patients with malignant cells in the CSF can aid in diagnosing CNS neoplasms.
\end{abstract}

KEY WORDS: central nervous system, cerebrospinal fluid, malignant cells, CNS neoplasm, CNS tumors.

\begin{abstract}
Características citológicas e bioquímicas do líquido cefalorraquidiano na presença de neoplasias no SNC

RESUMO - A infiltração neoplásica no SNC deve ser afastada em pacientes com neoplasia e sintomas neurológicos. Foi realizada uma análise retrospectiva de 1.948 amostras de LCR de pacientes com suspeita de infiltração neoplásica no SNC. Sessenta e dois por cento dos pacientes eram portadores de leucemia linfocitica aguda. Células neoplásicas foram encontradas em $24 \%$ de todas as amostras. Houve níveis aumentados no LCR da proteína total (PT), glicose e de citologia global $(p<0.05)$, no grupo com presença de células neoplásicas. A média da contagem global de células no LCR, neste grupo, foi $232 \pm 933 \mathrm{cels} / \mathrm{mm}^{3}$, contra $9 \pm 93$ cells $/ \mathrm{mm}^{3}$ no grupo sem células neoplásicas no LCR $(p=0,029)$. O aumento de PT no LCR apresentou especificidade $87 \%$ e valor preditivo negativo (VPN) $96 \%$. A contagem global de células no LCR apresentou especificidade $86 \%$ e VPN $97 \%$. Porém sensibilidade e valores preditivos positivos foram baixos. A presença de células inflamatórias e PT no LCR elevada em pacientes com neoplasias pode ser um indicador do envolvimento no SNC.
\end{abstract}

PALAVRAS-CHAVE: sistema nervoso central, líquido cefalorraquidiano, células neoplásicas, neoplasias.

The biochemical and cellular characteristics of the cerebrospinal fluid (CSF) are important for the diagnosis of the central nervous system (CNS) neoplasms'. The hypothesis of CNS involvement by malignant neoplasms must be made in a patient with known malignant neoplasms that presents neurological symptoms. Malignant cells of a variety of tumors, metastasis or primary, can be detected in the CSF. Any type of neoplasm can spread to the leptomeninges ${ }^{1-6}$. This dissemination occurs with more frequently in acute hematological diseases such as leukemia and lymphomas.
Among solid tumors, the dissemination is more frequent with melanomas and breast or lung cancer. Among CNS primary tumors, tumor cells are more commonly found in the CSF in gliomas and medulloblastomas, due to their higher incidence and tendency to spread into the subaracnoid space. The frequency of CNS primary lymphomas has increased over the past, and is particularly high in patients with cellular immunity alterations such as HIV $^{7-11}$.

The objective of this study was to evaluate the frequency of detecting malignant cells in CSF, to corre-

Clinical Pathology Laboratory - Hospital de Clínicas - Federal University of Paraná, Curitiba PR, Brazil (UFPR).

Received 22 January 2007, received in final form 13 April 2007. Accepted 29 May 2007.

Dr. Sérgio Monteiro de Almeida - Hospital de Clínicas / UFPR - Setor Análises Clínicas / Seção de Liquido Cefalorraquidiano - Rua Padre Camargo 280 - 80060-240 Curitiba PR - Brasil E-mail: sergio.ma@pop.com.br 
Table 1. Neoplastic disease of patients with CSF samples referred to search for malignant cells.

\begin{tabular}{|c|c|c|c|c|c|c|}
\hline \multirow[t]{2}{*}{ Indication } & \multicolumn{2}{|c|}{$\leq 14$ years $(n=270)$} & \multicolumn{2}{|c|}{$\geq 15$ years $(n=141)$} & \multicolumn{2}{|c|}{ Total $(n=411)$} \\
\hline & $\mathrm{N}$ & $\%$ & $\mathrm{~N}$ & $\%$ & $\mathrm{~N}$ & $\%$ \\
\hline ALL & 177 & 65.56 & 77 & 54.61 & 254 & 61.80 \\
\hline CML & 5 & 1.85 & 11 & 7.80 & 16 & 3.89 \\
\hline AML & 45 & 16.67 & 18 & 12.77 & 63 & 15.33 \\
\hline Lymphoma & 28 & 10.37 & 15 & 10.64 & 43 & 10.46 \\
\hline Retinoblastoma & 7 & 2.59 & 1 & 0.71 & 8 & 1.95 \\
\hline Others* & 8 & 2.96 & 19 & 13.48 & 27 & 6.57 \\
\hline Total & 270 & & 141 & & 411 & 100 \\
\hline
\end{tabular}

ALL, acute lymphocytic leukemia; AML, acute myelocytic leukemia; CML, chronic myelocytic leukemia. *lung, gastric, breast, melanoma, prostate, Ewing sarcoma, rabdomyossarcoma, glioblastoma, astrocytoma, Schwanoma, chronic lymphocytic leukemia (CLL).

Table 2. Positivity rate of malignant cells in CSF samples.

\begin{tabular}{lccc}
\hline Indication & N samples & Positive & $\%$ \\
\hline ALL & 254 & 63 & 24.8 \\
CML & 16 & 2 & 12.5 \\
AML & 63 & 13 & 20.6 \\
Lymphoma & 43 & 9 & 20.9 \\
Retinoblastoma & 8 & 4 & 50.0 \\
Others* & 27 & 7 & 25.9 \\
Total & 411 & 98 & 23.8 \\
\hline
\end{tabular}

$A L L$, acute lymphocytic leukemia; $A M L$, acute myelocytic leukemia; $C M L$, chronic myelocytic leukemia; *lung, gastric, breast, melanoma, prostate, Ewing sarcoma, rabdomyossarcoma, glioblastoma, astrocytoma, Schwanoma, chronic lymphocytic leukemia (CLL).

late it with CSF cytological and biochemical characteristics and to study the validity of basic CSF characteristics for the diagnosis of CNS malignant involvement.

\section{METHOD}

A retrospective, longitudinal study was conducted utilizing the CSF laboratory (lab) results from the from the data files of the CSF section of the clinical pathology laboratory of the General Hospital- Paraná Federal University (UFPR). The CSF samples were from adults and children with clinical suspicion of malignant CNS infiltration and from patients that underwent prophylactic intrathecal chemotherapy referred to the lab, mainly from hematology, bone marrow transplantation, neurology and neurosurgery services. The study period was from March 1995 to December 2000.

CSF total protein (TP) was determined by turbidimetric method of sulphosalicylic acid and CSF glucose was determined by enzymatic method. CSF total cell count was assessed by a Fuchs Rosenthal chamber. For differential cell count and to detect the presence of malignant cells, CSF samples were concentrated by Suta Chamber (from 1995 to 1998) and Cytospin (from 1998 to 2000). CSF samples were protein enriched with albumin. The slides were stained by May Grünwald-Giensa technique and analyzed by at least two trained researchers (SMA and EN). Malignant cells were defined by the presence of one or more of these characteristics, in accordance with the clinical diagnosis: large size and/or nuclei; nucleus/cytoplasm size index increased in favor of the nucleus; multiple nuclei; great, prominent or multiple nucleoli; variation in the size and format of the cells and nuclei; mitosis in groups of cells, frequent atypical mitosis; irregular nuclear edges, hyperchromasia and irregular grouping of the nuclear chromatin.

During the study period were referred to the CSF lab 1,948 CSF samples from 331 patients with possible malignant CNS infiltration, 180 patients (54.4\%) were male and $151(45.6 \%)$ were female, and the mean age was 15.7 years $( \pm 15.8)$ (mean \pm SD); median 9 years. All CSF samples were collected by lumbar puncture (LP) with a total of 1948 referring CSF samples. LP was repeated $6 \pm 5$ times; median of 4 times.

Statistical analysis - To calculate the positivity rate of detecting malignant cells in CSF, we considered the first sample, positive or negative, of each patient, and all subsequent positive samples (total number of 411 samples).

For analysis of the results, the CSF samples were divided in two groups with neoplasic cells and without neoplasic cells. The continuous variables were compared using the non parametric Wilcoxon statistical test; the categorical variables were compared using Chi-square test $\left(\chi^{2}\right)$. A $p$ value $\leq 0.05$ was considered significant. The results were presented as mean \pm SD.

\section{RESULTS}

The indications to detect malignant cells in the CSF, classified by age groups, are indicated in Table 1. The main indication was acute lymphocytic leukemia (ALL) in both age groups followed by acute myelogenous leukemia (AML) and lymphoma.

Malignant cells were found in 98 of the 411 samples $(23.84 \%)$. The positivity rates by malignant disease are indicated in Table 2.

CSF biochemical (total protein and glucose) and cytological characteristics of CSF samples, in the groups with and without malignant cells, are indi- 
Table 3. Biochemical and cytological characteristics of CSF samples referred to search for malignant cells.

\begin{tabular}{|c|c|c|c|c|c|}
\hline \multirow{2}{*}{ CSF } & \multicolumn{2}{|c|}{ Malignant cells present (n 98) } & \multicolumn{2}{|c|}{ Without malignant cells ( $n$ 1850) } & \multirow[t]{2}{*}{$P * *$} \\
\hline & $\mathrm{N}$ & mean $\pm S D$ & $\mathrm{~N}$ & mean \pm SD & \\
\hline $\mathrm{TP} \mathrm{mg} / \mathrm{dL}$ & 89 & $69.46 \pm 132.45$ & 1718 & $38.60 \pm 139.11$ & 0,642 \\
\hline Glucose $\mathrm{mg} / \mathrm{dL}$ & 97 & $54.27 \pm 23.58$ & 1819 & $55.54 \pm 18.64$ & 0.882 \\
\hline Cells $/ \mathrm{mm}^{3}$ & 98 & $232.19 \pm 932.55$ & 1850 & $8.79 \pm 92.99$ & $0.029 *$ \\
\hline
\end{tabular}

*significant value; **test of Wilcoxon.

Table 4. Number of samples with CSF biochemical and cytological characteristics altered.

\begin{tabular}{|c|c|c|c|c|c|}
\hline \multirow[t]{2}{*}{ CSF } & \multicolumn{2}{|c|}{ Malignant cells present (n 98) } & \multicolumn{2}{|c|}{ Without malignant cells ( $n$ 1850) } & \multirow[t]{2}{*}{$\mathrm{P} * *$} \\
\hline & $\mathrm{N}$ & $\%$ & $\mathrm{~N}$ & $\%$ & \\
\hline $\mathrm{TP} \geq 45 \mathrm{mg} / \mathrm{dL}$ & 33 & 37 & 226 & 13.1 & $<0.0001$ * \\
\hline Cells $\geq 4 / \mathrm{mm}^{3}$ & 57 & 58.1 & 260 & 14.1 & $<0.0001 *$ \\
\hline Glucose $\leq 45 \mathrm{mg} / \mathrm{dL}$ & 34 & 35.0 & 382 & 21.0 & $0.0017 *$ \\
\hline
\end{tabular}

*significant value; ** $\chi^{2}$ test.

Table 5. Differential cytology of CSF samples referred to search for malignant cells (number of cases with cells present).

\begin{tabular}{|c|c|c|c|c|c|}
\hline \multirow[t]{2}{*}{$\mathrm{CSF}$} & \multicolumn{2}{|c|}{ Malignant cells present (n 98) } & \multicolumn{2}{|c|}{ Without malignant cells ( $\mathrm{n} 1850$ ) } & \multirow[t]{2}{*}{$\mathrm{P} * *$} \\
\hline & $\mathrm{N}$ & $\%$ & $\mathrm{~N}$ & $\%$ & \\
\hline$\%$ monocytes & 25 & 25.5 & 99 & 5.3 & $<0.0001 *$ \\
\hline \% lymphocytes & 36 & 36.7 & 212 & 11.4 & $<0.0001 *$ \\
\hline$\%$ neutrophils & 13 & 13.2 & 60 & 3.2 & $<0.0001 *$ \\
\hline$\%$ basophiles & 2 & 2.0 & 2 & 0.2 & $0.0141 *$ \\
\hline$\%$ plasmocytes & 1 & 1.0 & 3 & 0.1 & 0.1866 \\
\hline$\%$ eosinophils & 1 & 1.0 & 4 & 0.3 & 0.2276 \\
\hline$\%$ macrophages & 2 & 2.0 & 11 & 0.6 & 0.1362 \\
\hline
\end{tabular}

*significant value; ** $\chi^{2}$ test.

Table 6. CSF biochemical and cytological characteristic parameters for the diagnosis of CNS malignant infiltration.

\begin{tabular}{lccc}
\hline & $\begin{array}{c}\text { Protein } \\
\leq 45 \mathrm{mg} / \mathrm{dL}\end{array}$ & $\begin{array}{c}\text { Glucose } \\
\leq 45 \mathrm{mg} / \mathrm{dL}\end{array}$ & $\begin{array}{c}\text { Cells } \\
\geq 4 / \mathrm{mm}^{3}\end{array}$ \\
\hline Sensitivity (\%) & 37.0 & 35.0 & 58.1 \\
Specificity (\%) & 86.8 & 78.9 & 85.9 \\
PPV (\%) & 12.7 & 8.1 & 17.9 \\
NPV (\%) & 96.3 & 95.8 & 97.4 \\
Youden index (\%) & 23.8 & 13.9 & 44.0 \\
\hline
\end{tabular}

cated in Table 3. CSF TP was higher by almost two times in the group with presence of malignant cells $(69.5 \pm 132.5 \mathrm{mg} / \mathrm{dL})$, than the group without malignant cells $(38.6 \pm 139.1 \mathrm{mg} / \mathrm{dL})$ although there was no statistical difference $(p=0.642)$. The percentages of cases with TP higher than $45 \mathrm{mg} / \mathrm{dL}$ and glucoses lower than $45 \mathrm{mg} / \mathrm{dL}$ are higher in the group with presence of malignant cells (Table 4).

The mean \pm SD of CSF total cell count was higher in the group with malignant cells $(232.2 \pm 932.6$ cell $\left./ \mathrm{mm}^{3}\right)$, than in the group without malignant cells $\left(8.8 \pm 93\right.$ cells $\left./ \mathrm{mm}^{3}\right)(p=0.029)$ (Table 3 and 4$)$.

In the group with malignant cells, the number of samples containing lymphocytes, monocytes and neutrophils was greater than in the group without malignant cells (Table 5).

CSF TP ( $\geq 45 \mathrm{mg} / \mathrm{dL})$, glucose $(\leq 45 \mathrm{mg} / \mathrm{dL})$ and an increase in CSF total cell count could be specific for indication of the presence of malignant cells in the CSF and has high negative predictive value (Table 6). 


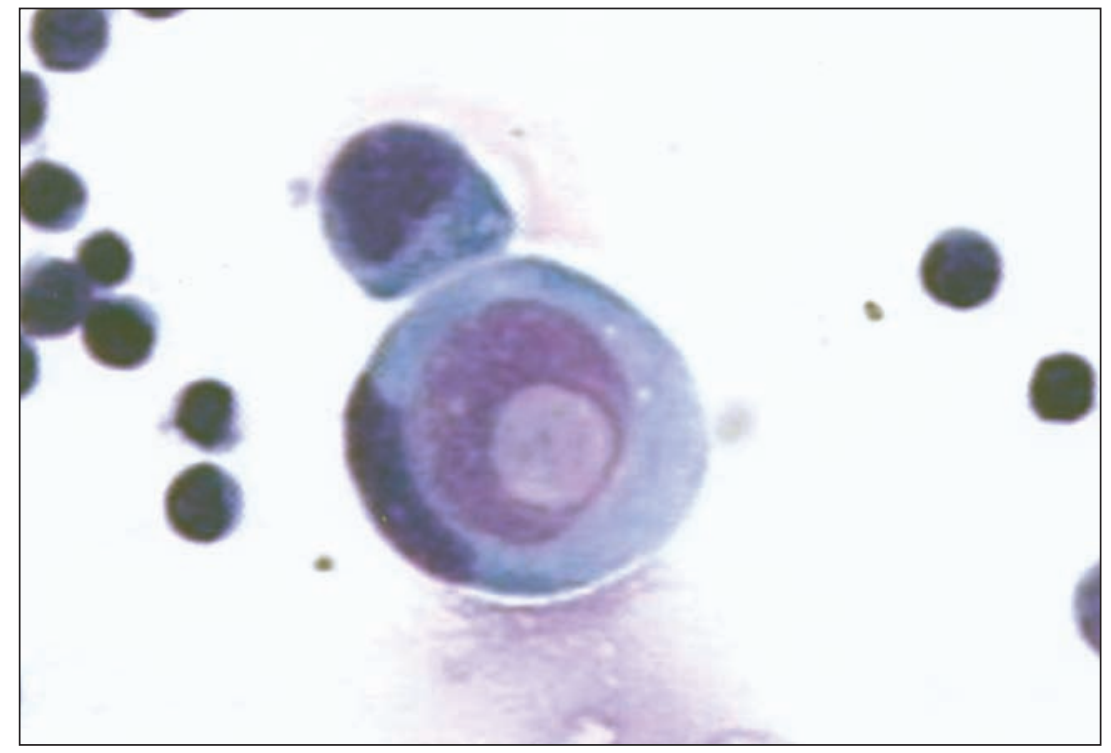

Fig 1. CSF, breast adenocarcinoma cell, Light microscopy (May-Grünwald/Giensa stain, 1,000X). Presence of degenerative vacuoles in the cytoplasm, the nucleus has hyperchromasia. The cell in the center is phagocyting other cell (cell autophagy). There are normal lymphocytes around the malignant cell (note the difference in size between the cells).

\section{DISCUSSION}

This manuscript reports the findings of a single institution retrospective review of CSF analysis of patients suspect of having CNS malignant disease. In patients with well-known malignant neoplasm presenting with neurological symptoms, the diagnosis of leptomeninges infiltration must be ruled out ${ }^{12}$ since any type of neoplasm is potentially capable of spreading to the leptomeninges. The diagnosis of the involvement of the meninges by extraneural cancer, leukemia cells, lymphomas and CNS primary tumors is based on cytological confirmation, either through CSF cytology or biopsy of leptomeninge ${ }^{13}$. The rate of positive CSF cytology found in our lab (24\%) is a mean value compared to rates reported ${ }^{12,14,15}$, and is in accordance with some studies ${ }^{14,16}$. However, the positivity rate of detecting malignant cells in the CSF varies in the literature and is assumed to depend on several factors such as histological confirmation, local of CSF collection, and CSF processing methodology used for cells concentration as sedimentation chambers or cytospin ${ }^{17-19}$. The sensitivity of detecting malignant cells in the CSF changes in accordance with the type of neoplasm, anatomic location as well as with the presence of meningeal involvement and its extension and number of malignant cells in $\mathrm{CSF}^{9,12,14}$. Primary cerebral tumors that exfoliated cells to the CSF were all located adjacent to the ventricle. In contrast, cells from tumors deeply localized in cerebral parenchyma are more difficult to be found in the $\mathrm{CSF}^{15,16}$.

In our laboratory the most frequent indication to attempt to detect the presence of malignant cells in the CSF was ALL. The percentage of positivity

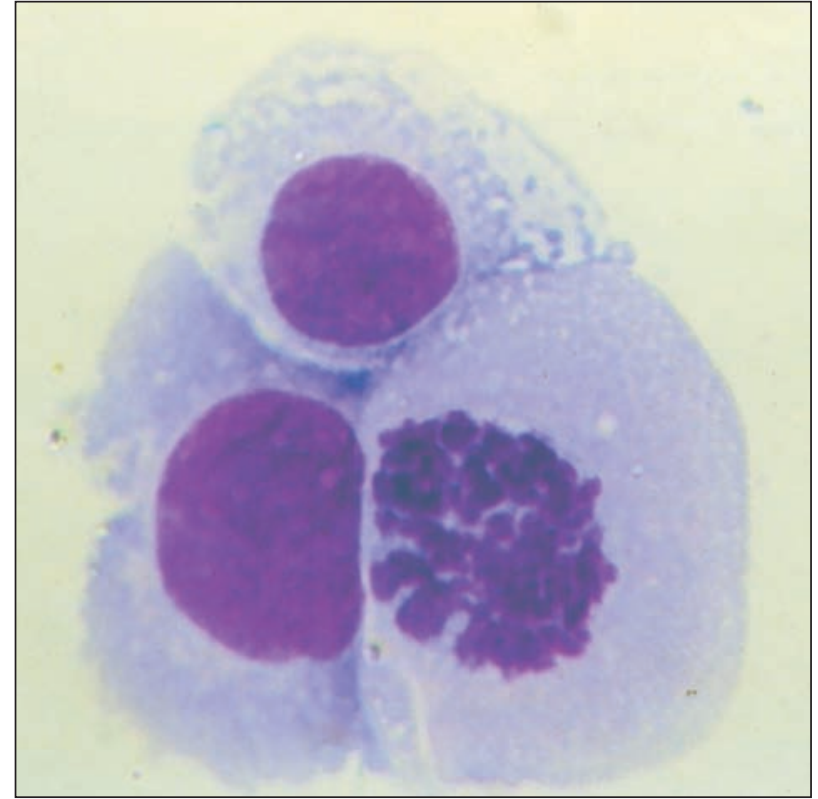

Fig 2. CSF, lung adenocarcinoma cell, Light microscopy (MayGrünwald/Giensa stain, 1,000X). The cell borders are irregular and the nucleus has hyperchromasia. The nucleus of the cell at right shows atypical mitosis

we found is in accordance with the rate of CNS involvement of ALL in patients who routinely receive prophylactic intrathecal chemotherapy. For lymphoproliferative diseases, approximately $80 \%$ of the patients with ALL and $60 \%$ of patients with untreated acute myelogenous leukemia (AML) have leukemia cells in the CSF, during some period of the disease. With the use of intrathecal chemotherapy the incidence of acute leukemia in the CNS decreased to approximately $10 \%{ }^{9}$. In contrast with acute leukemias, the involvement of the CNS by chronic leukemias, 
Fig 3. CSF, primary CNS lymphoma associated with HIV infection, Light microscopy (May-Grünwald/Giensa stain, 1,000X). Nucleus/cytoplasm index altered presence of multiples nucleoli.

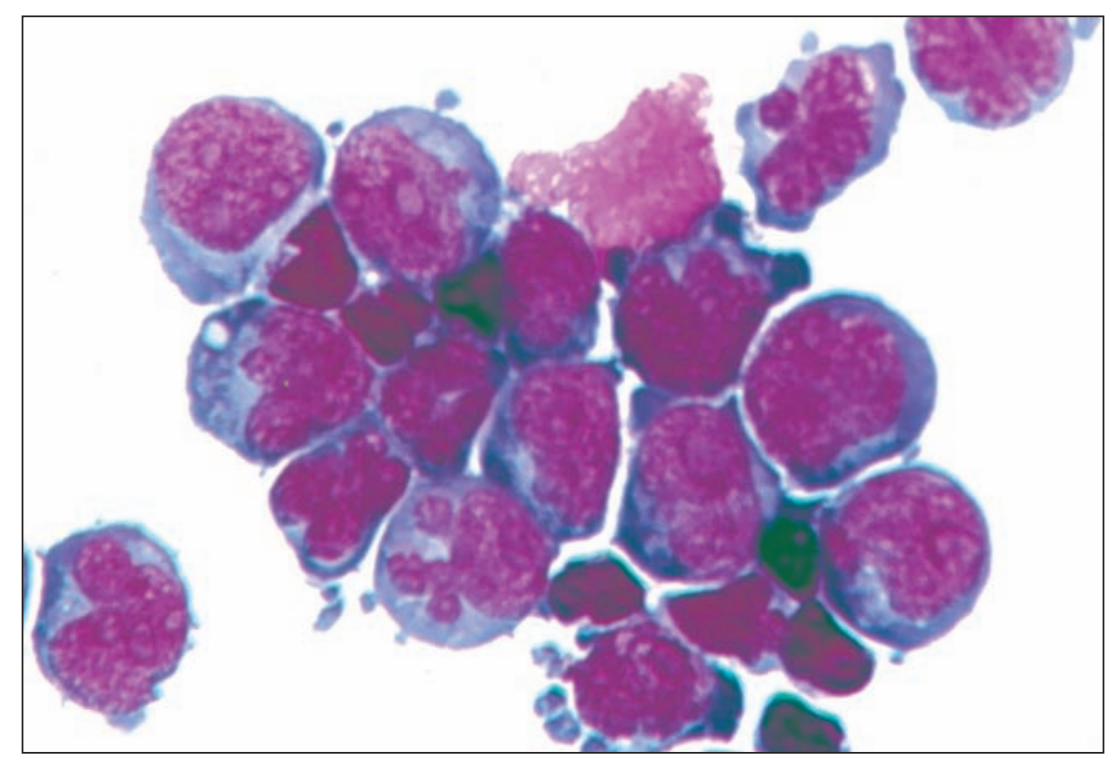

such as chronic lymphocytic leukemia (CLL) and also chronic myeloid leukemia (MCL), is not common'. For patients with diffuse non-Hodgkin lymphoma the involvement of leptomeninges has been reported in 5 to $27 \%$ of the patients 9 .

The percentage of detection of CNS primary tumors cells in the CSF varies from 7.3 to $69.2 \%$, the detection of gliomas and medulloblastomas cells is more frequent. In the case of CNS primary lymphomas, approximately 20 to $30 \%$ of the patients present with neoplasm cells in the $\mathrm{CSF}^{9}$.

The malignant cells usually are strange cells to the CSF environment, differing from the cells frequently seen in the CSF. Some cellular characteristics could indicate possible malignant involvement in the CSF (Figs 1, 2 and 3). None of these isolated characteristics are patognomonic of neoplasm 9 ; for exemple atypical cellular mitosis can also be observed in benign conditions such as acute meningitis ${ }^{20}$. However, the association of criteria can make the diagnosis of malignancy most likely?

The presence of a uniform cellular population in the CSF with a similar nucleus to the blastic cells and scarce cytoplasm can be signs of involvement of meninges by leukemia. When a uniform population of blastic cells is present in great number, the diagnosis of CNS involvement by leukemia is not difficult. However the diagnosis becomes difficult if only a small number of blasts are present ${ }^{9}$. Falsepositive results can be observed in viral infections, arachnoiditis or in cases of intrathecal chemotherapy. In reactive pleocytosis with presence of lymphocytes and/or monocytes, a more heterogeneous cellular population frequently is found. Viral infections and chemotherapy can transform normal mononuclear cells into similar blastic cells ${ }^{9}$. A false-positive result can also result from the contamination of the CSF by peripheral blood with blastic cells, contamination of the CSF with bone marrow cells $s^{21,22}$ or during a period of immunologic reconstitution ${ }^{9}$.

There is no absolute consensus about the definition of the involvement of CNS in leukemias. A CSF total cytology increase of more than 5 cells $/ \mathrm{mm}^{3}$ is considered diagnostic with the unequivocal presence of blastic cells ${ }^{23}$. According to some authors a falsepositive diagnosis can be prevented by diagnosing only neuroleukemia in the presence of immature cells representing at least $40 \%$ to $60 \%$ of the total cell population ${ }^{24}$.

Cellular and biochemical CSF characteristics - Little attention has been given to the routine analysis of the CSF and its relationship to the clinical data on tumoral pathology ${ }^{15,16,25-29}$. Our data showed that total CSF cell count was greater in the group with malignant cells than the group without malignant cells, consisting predominantly of lymphocytes and monocytes and in some cases neutrophils supporting reports from other studies ${ }^{15,16}$. Furthermore, other studies report an increase in total CSF cell count in 33 to $79 \%$ of cases studied of approximately 68 cells/ $\mathrm{mm}^{3}$, ranging from 18 to 685 cells $/ \mathrm{mm}^{3}$. The predominance of polimorphonuclear cells was found in $44 \%$ of the $\operatorname{cases}^{12,13}$. For some authors these cellular reactions are in part due to previous surgery ${ }^{15}$. However, this is not the case in the majority of the patients in our study who were with ALL. On the other hand, in 
these cases, intrathecal prophilatically chemotherapy could partially explain this pleocythosis.

In this study, polymorphonuclear cells were found in $13 \%$ of samples with malignant cells present and in $3 \%$ of samples without malignant cells $(p<0.0001)$. The presence of polymorphonuclear in the CSF is considered pathological; however after the introduction of more efficient concentration techniques, some researchers consider that a small number of neutrophils can be present in normal $\mathrm{CSF}^{30}$. The reference values of neutrophils are $2 \%$ for adults and $4 \%$ for newborns. In general, it is recommended to always consider the presence of a small number of neutrophils in the clinical context and in relation to the results of other laboratory tests.

In this study, CSF TP was mildly increased (in relation to normal) in the group with malignant cells present. The increase of CSF TP in the group with presence of malignant cells was almost two times greater than the CSF TP in the group without malignant cells, however, this increase was not statistically significant. Our study reports an increase of CSF TP in $37 \%$ of samples with involvement of leptomeninges by neoplasm which is less than previous reports citing increases of 76 to $86 \%$ in cases with neoplasms ${ }^{12}$. The increase in CSF TP in combination with multifocal neurological symptoms or alterations upon neuroimaging examinations was found in $73 \%$ of the patients with negative malignant cells in the first sample of CSF. The association of increased CSF TP and multifocal neurological symptoms or altered neuroimaging tests, preferential MRI, can indicate involvement of meninges in the neoplasm. Therefore, although not specific, the increase of the CSF TP has value in patients whose first sample of CSF was negative for malignants cells and a previous diagnosis of neoplasm ${ }^{12}$.

Other reports have already described increased values of CSF TP content in several types of cerebral tumors ${ }^{16,25}$. This CSF TP increase could be related to intracranial hypertension and increased permeability of the blood brain barrier that is demonstrated by a transudative protein pattern. Moreover, this pattern was found in cerebral tumors with higher incidence than the degenerative or gamma-globulin patterns ${ }^{16}$. Decrease of glucose has been reported in 29 to $56 \%^{12,13}$ and our findings are in accordance ${ }^{1,9}$.

Our results must be seen carefully because the majority of patients in this study received intrathecal chemotherapy. As this confound factor is present in both groups probably this didn't interfere on our results.
For CSF TP, glucose and total cell count, the sensitivity of these parameters, isolated studied, for the indication of presence of malignant cells in CSF of patients with clinical suspicion was low but specifity was high. In samples with a moderate increase of CSF WBC (11-50 cells $/ \mathrm{mm}^{3}$ ) the sensitivity for the presence of malignant cells increases and with cells more than 200 cells $/ \mathrm{mm}^{3}$ the positive predictive value increases.

A high CSF TP (above of $45 \mathrm{mg} / \mathrm{dL}$ ) and a low CSF glucose (less than $45 \mathrm{mg} / \mathrm{dL}$ ) along with the number of CSF total cell count have high Negative Predictive Value (NPV) indicating that normal values of CSF TP and glucose in samples from patients with clinical suspicion of CNS infiltration could help to indicate absence of CNS neoplastic infiltration. There is no change in NPV increasing the value of the cut off of $T P$, glucose and CSF total cell count.

Methods with more sensibility and specificity than the cellular morphology are necessary to correctly identify malignant cells in the CSF. Although CSF cytology is useful, malignant cells are not detected in as many as one third of patients who have compelling clinical or radiographic evidence of neoplastic meningitis. Novel assays are being tested that may enhance the early identification of malignant cells in CSF. Currently, the diagnosis occurs generally after the onset of neurologic manifestations and heralds a rapidly fatal course for most patients ${ }^{27}$. Imunocytochemistry techniques, immunophenotipagem and biochemical or immunologic markers can help in this diagnosis $7,8,10,27-34$. The analysis of CSF biochemical and cellular characteristics, although not specific for the diagnosis of malignant involvement of CNS, are important and can help for the diagnosis of CNS neoplasm when associated with other clinical or biomarker characteristics.

\section{REFERENCES}

1. Fishman RA. Cerebrospinal fluid in diseases of the nervous system. 2.Ed. Philadelphia: WB Saunders, 1992..

2. Browne TJ, Goumnerova LC, De Girolami U, et al. Cytologic features of piloctic astrocytoma in cerebrospinal fluid specimens. Acta Cytol 2004; 48:3-8.

3. Glosova L, Dundr P, Effler J, et al. Gallbladder carcinoma cells in cerebrospinal fluid as the first manifestation of a tumor: a case report. Acta Cytol 2003;47:1087-1090.

4. Livramento JA, Machado LR, Clemente HAM, Tabares-Olives A, SpinaFrança A. Melanomatose meningea: análise citomorfologica do líquido cefalorraqueano. Arq Neuropsiquiatr 1979;37:7-14.

5. Moraes-Rêgo SF, Moraes-Rêgo KG. Exame citológico do líquido céfalo-raquidiano no diagnóstico de neoplasias primitivas ou metastáticas do sistema nervoso. Arq Neuropsiquiatr 1986;44:165-173.

6. Rolim JAB, Barsottini OGP, Prado GF, Nakandakare F, Reis MLAA, Reis-Filho JB. Líquido cefalorraquidiano no diagnóstico de metástase cérebro-meníngea de melanoma maligno derivado de nevo melanocítico gigante congênito. Arq Neuropsiquiatr 1996;54:479-483 
7. Bossolasco S, Nilsson A, Milito A, et al. Soluble CD23 in cerebrospinal fluid: a marker of AIDS related non-Hodgkin's lymphoma in the brain. AIDS 2001;15:1109-1113.

8. Murare S, Saio M, Takenaka K, et al. Increased levels of CSF soluble CD27 in patients with primary central nervous system lymphoma. Cancer Lett 1998;132:181-186.

9. Kjeldsberg CR, Knight JA. Body fluids. Chicago: American Society of Clinical Pathologists, 1993:65-157.

10. De Luca A, Antinori A, Cingolani A, et al. Evaluation of cerebrospinal fluid EBV-DNA and IL-10 as markers for in vivo diagnosis of AIDS-related primary central nervous system lymphoma. British J Haematol 1995;90:844-849.

11. Sadler M, Brink NS, Gazzard BG. Management of intracerebral lesions in patients with HIV: a retrospective study with discussion of diagnostic problems. Q J Med 1998;91:205-217.

12. Van Oostenbrugge RJ, Twijnstra A. Presenting features and value of diagnostic procedures in leptomeningeal metastases. Neurology 1999;53: 382-385.

13. Balm M, Hammack J. Leptomeningeal carcinotasis: presenting features and prognostic factors. Arch Neurol 1996;53: 626-632.

14. Glass JP, Melamed M, Chernik NL, et al. Malignant cells in cerebrospinal fluid (CSF): the meaning of a positive CSF cytology. Neurology 1979;29:1369-1375.

15. Watson CW, Hajdu SI. Cytology of primary neoplasm of the central nervous system. Acta Cytol 1977;21:40-47.

16. Sá MJ, Vaz R, Cruz C. Cerebrospinal fluid cytomorphologic findings in 41 intracranial tumors. Arq Neuropsiquiatr 1995;53:218-226.

17. Rogers LR, Duchesneau PM, Nunez C, et al. Comparison of cisternal and lumbar CSF examination in leptomingeal metastasis. Neurology 1992;42:1239-1241.

18. Glantz MJ, Cole BF, Glantz LK, et al. Cerebrospinal fluid cytology in patients with cancer: minimizing false-negative results. Cancer 1998; 82:733-739.

19. Spina-França A, Machado ABB, Pasqualin JR. Técnica de suta e identificação de células neoplásicas no líquido cefalorraquidiano. Arq Neuropsiquiatr 1971;29:463-466.

20. De Reuck J, Vanderdonckt P, de Bleecker J, et al. Mitotic activity in cerebrospinal fluid cells. Clin Neurol Neurosurg 1988;90:117-119.

21. Lane PA, Githens JH. Contamination of cerebrospinal fluid with bonemarrow cells during lumbar puncture. N Engl J Med 1983;309:434-435.
22. Luban NLC, Alessi RM, Gold BG, et al. Cerebral spinal fluid pleocytosis with bone marrow contamination. J Pediatr 1984;104:254-256.

23. Mastrangelo R, Poplack D, Bleyer A, et al. Report and recommendations of the Rome Workshop concerning poor prognosis in acute lymphoblastic leukemia in children: biologic bases for staging, stratification, and treatment. Med Pediatr Oncol 1986;14:191-194.

24. Aaronson AG, Hadju SI, Melamed MR. Spinal fluid cytology during chemotherapy of leukemia of the central nervous system in children. Am J Clin Pathol 1975;63:523-537.

25. Van Zanten AP, Twijnstra A, Ongerboer de Visser BW. Routine investigation of the CSF with special reference to meningeal malignancy and infectious meningitis. Acta Neurol Scand 1988;77:210-214.

26. Watson MA, Scott MG: Clinical utility of biochemical analysis of cerebrospinal fluid. Clin Chem 1995;41:343-360.

27. Faller DV, Mentzer SJ, Perrine SP: Induction of the Epstein-Barr virus tymidine kinase gene with concomitant nucleoside antivirals as a therapeutic strategy for Epstein-Barr virus associated malignancies. Curr Opin Oncol 2001;13:360-367.

28. Weller M, Stevens A, Sommer N, et al. Humoral CSF parameters in the differential diagnosis of hematologic CNS neoplasia. Acta Neurol Scand 1992;86:129-133.

29. Kleine TO, Zwerenz P, Zofel P, et al. New and old diagnostic markers of meningitis in cerebrospinal fluid (CSF). Brain Research Bull 2003;61: 287-297.

30. Hayward RA, Oye RK. Are polymorphonuclear leukocytes an abnormal finding in cerebrospinal? Results from 225 normal cerebrospinal fluid specimens. Arch Intern Med 1988;148:1623-1624.

31. Kim L, Glantz MJ. Neoplastic meningitis. Curr Treat Options Oncol 2001;2:517-527.

32. Freilich RJ, Krol G, De Angelis LM. Neuroimaging and cerebrospinal fluid cytology in the diagnosis of leptomeningeal metastasis. Ann Neurol 1995;38:51-57.

33. Sampath $\mathrm{P}$, Weaver CE, Sungarian A, et al. Cerebrospinal fluid (vascular endothelial growth factor) and serologic (Recoverin) tumor markers for malignant glioma. Cancer Control 2004;11:174-180.

34. Hug A, Storch-Hagenlocher B, Haas J, et al. Single-cell PCR analysis of the immunoglobulin heavy-chain CDR3 region for the diagnosis of leptomeningeal involvement of B-cell malignancies using standard cerebrospinal fluid cytospins. J Neurol Sci 2004;219:83-88. 